\title{
Seasonal variations of melatonin in ram seminal plasma are correlated to those of testosterone and antioxidant enzymes
}

\author{
Adriana Casao*1, Igor Cebrián22, Mayra Eoda Asumpção33, Rosaura Pérez-Pé1, José A Abecia4, Fernando Forcada4, \\ José A Cebrián-Pérez and Teresa Muiño-Blanco
}

\begin{abstract}
Background: Some breeds of sheep are highly seasonal in terms of reproductive capability, and these changes are regulated by photoperiod and melatonin secretion. These changes affect the reproductive performance of rams, impairing semen quality and modifying hormonal profiles. Also, the antioxidant defence systems seem to be modulated by melatonin secretion, and shows seasonal variations. The aim of this study was to investigate the presence of melatonin and testosterone in ram seminal plasma and their variations between the breeding and nonbreeding seasons. In addition, we analyzed the possible correlations between these hormones and the antioxidant enzyme defence system activity.

Methods: Seminal plasma from nine Rasa Aragonesa rams were collected for one year, and their levels of melatonin, testosterone, superoxide dismutase (SOD), glutathione reductase (GRD), glutathione peroxidase (GPX) and catalase (CAT) were measured.

Results: All samples presented measurable quantities of hormones and antioxidant enzymes. Both hormones showed monthly variations, with a decrease after the winter solstice and a rise after the summer solstice that reached the maximum levels in October-November, and a marked seasonal variation $(P<0.01)$ with higher levels in the breeding season. The yearly pattern of GRD and catalase was close to that of melatonin, and GRD showed a significant seasonal variation $(P<0.01)$ with a higher activity during the breeding season. Linear regression analysis between the studied hormones and antioxidant enzymes showed a significant correlation between melatonin and testosterone, GRD, SOD and catalase.

Conclusions: These results show the presence of melatonin and testosterone in ram seminal plasma, and that both hormones have seasonal variations, and support the idea that seasonal variations of fertility in the ram involve interplay between melatonin and the antioxidant defence system.
\end{abstract}

\section{Background}

Melatonin plays a central role in fine-tuning circadian rhythms [1] and seasonal changes [2] through its daily nocturnal increase in the blood [3]. In seasonally breeding mammals that use changes in the photoperiod to time

\footnotetext{
* Correspondence: adriana@unizar.es

1 Departamento de Bioquímica y Biología Molecular y Celular, Grupo Biología y Fisiología de la Reproduction (BIOFREZ), Instituto Universitario de Investigation en Ciencias Ambientales de Aragón (IUCA), Facultad de Veterinaria,

Universidad de Zaragoza, Spain

Full list of author information is available at the end of the article
}

their reproductive cycles, temporal signals to the reproductive system are controlled by the daily rhythm in melatonin production [4-7]. Certain breeds of sheep are highly seasonal in terms of reproductive capability, regulated by photoperiod and melatonin secretion $[8,9]$. Therefore, seasonal melatonin variation has been thoroughly studied in this specie, and although seasonality is less marked in male than in female, changes in testicular volume, hormonal profiles, sexual behaviour and semen 
quality that affect the reproductive performance of rams have been reported [10-14].

Rasa Aragonesa is a local Spanish genotype with a short seasonal anoestrous period ( $<100$ days) between May and July [15]. In previous studies on this breed, we showed that the treatment of rams with slow release implants of melatonin during the non-breeding season accounted for increased scrotal diameter and improved the reproductive performance of ewes naturally mated [16] or inseminated during anoestrus with semen from these melatonin-implanted males [17]. Likewise, we have recently demonstrated a beneficial direct action of melatonin on sperm motility [17] and on other ram sperm characteristics during the non-breeding season, with decreased apoptotic-like changes and modulating capacitation [18].

Oxidative stress is defined as an imbalance between the cellular antioxidant defense systems and the production of reactive oxygen species (ROS) [19]. The antioxidant ability to scavenge ROS of mammalian sperm and seminal plasma allows maintaining the balance between ROS generation and neutralization. We have shown certain seasonal changes in the activity of the antioxidant enzyme defence system in ram seminal plasma [20] which could partly explain the seasonal variations in fertility observed in the ram [21]. In addition, the activity and expression of antioxidant enzymes seem to be modulated not only by the oxidant status of the cell but also by other factors like the presence of melatonin $[22,23]$. Therefore, we could hypothesize that seasonal difference in ram sperm quality might be regulated by the presence of melatonin in seminal plasma along with antioxidant enzyme activity which could prevent the oxidative damage of spermatozoa.

To further the understanding of the melatonin influence in ram semen, in this study we determined the presence of melatonin and testosterone in ram seminal plasma and investigated their variations between the breeding and non-breeding seasons. In addition, we analyzed the possible correlations between these hormones and the antioxidant enzyme defence system, comprising superoxide dismutase (SOD), glutathione reductase (GRD), glutathione peroxidase (GPX) and catalase (CAT).

\section{Methods}

\section{Experimental design and semen collection}

We determined the level of melatonin and testosterone, and the activity of the antioxidant enzyme defence system in ram seminal plasma throughout the year by weekly analysis. Correlations between the levels of both hormones and the activity of superoxide dismutase (SOD), glutathione reductase (GRD), glutathione peroxidase
(GPX) and catalase (CAT) were also determined, as well as variations between breeding and non-breeding seasons.

Semen was collected from nine Rasa Aragonesa rams maintained under uniform nutritional conditions at the Experimental Farm of the University of Zaragoza, Spain (latitude $41^{\circ} 41^{\prime} \mathrm{N}$, under Mediterranean climate conditions), in compliance with the requirements of the European Union for Scientific Procedure Establishments. All experimental procedures were performed under the supervision of the Ethics Committee of the University of Zaragoza. All the rams belonged to the National Association of Rasa Aragonesa Breeding (ANGRA) and were 2-4 years old. The sires were kept apart, and semen was collected every two days, in two successive matings each day. First and second ejaculates were pooled separately to obtain a uniform, good quality sperm sample suitable for representative studies of ram semen, according to previous report [24]. Only first ejaculate samples were used in this study.

\section{Seminal plasma extraction}

Seminal plasma was extracted from pooled first ejaculates by centrifugation at $2.400 \times \mathrm{g}$ for $10 \mathrm{~min}$ in a microfuge at $4^{\circ} \mathrm{C}$. The supernatant was centrifuged again at $2.400 \times \mathrm{g}$ for $10 \mathrm{~min}$, and seminal plasma was recovered and, after filtering through a $0.22 \mu \mathrm{m}$ Millipore membrane (Millipede Ibérica, Madrid, Spain) was kept at $-20^{\circ} \mathrm{C}$ until analysed. Two seminal plasma samples obtained per week were pooled and analyzed.

\section{Melatonin evaluation}

Melatonin values in ram seminal plasma were measured by means of a commercial competitive immunoassay (Direct saliva melatonin ELISA kit, Bühlmann Laboratories AG, Switzerland, sensitivity: $0.5 \mathrm{pg} / \mathrm{ml}$, intro-assay variability: $5.2 \%$ ), following the manufacturer's instructions. Briefly, $100 \mu \mathrm{l}$ of each sample, control and calibrator were loaded in duplicate in a microtiter plate coated with an anti-melatonin antibody, and incubated for 16-20 $\mathrm{h}$ at $2-8^{\circ} \mathrm{C}$. After incubation, $50 \mu \mathrm{l}$ of biotinylated melatonin were added to each well and incubated for $3 \mathrm{~h}$ at 2$8^{\circ} \mathrm{C}$. After three washes, $100 \mu \mathrm{l}$ of streptavidin conjugated to horseradish peroxidase (HRP) were loaded to the wells and incubated for a further $60 \mathrm{~min}$ in a plate rotator set at $600 \mathrm{rpm}$ at $18-28^{\circ} \mathrm{C}$. Wells were washed three times again, and $100 \mu \mathrm{L}$ of tetramethylbenzidine substrate (TMB) were added to each well and incubated for $30 \mathrm{~min}$ on a plate rotator at $600 \mathrm{rpm}$ and $18-28^{\circ} \mathrm{C}$ and protected from direct light. After incubation, $100 \mu \mathrm{l}$ of $0.25 \mathrm{M}$ $\mathrm{SO}_{4} \mathrm{H}_{2}$ solution were added and absorbable was measured on a microtiter plate reader (TECAN Spectrafluor plus, Switzerland) at $450 \mathrm{~nm}$. 


\section{Testosterone assays}

Testosterone evaluation in ram seminal plasma was performed by means of a total testosterone commercial ELISA kit assay (Testo-Easia, BioSource Europe, S.A., Belgium. sensitivity: $0.05 \mathrm{ng} / \mathrm{ml}$, intro-assay variability: $4.8 \%$ ), following the manufacturer's instructions. Briefly, $50 \mu \mathrm{l}$ of each sample, control and calibrator, along with $100 \mu \mathrm{l}$ of testosterone labeled with horseradish peroxidase (HRP) were loaded in duplicate in a microtiter plate coated with an anti-testosterone specific antibody, and incubated for $1 \mathrm{~h}$ at room temperature. After incubation, wells were washed three times, and $100 \mu$ l of chromogenic substrate (TMB) were added to each well and incubated for $30 \mathrm{~min}$ at room temperature, protected from direct light. After incubation, $100 \mu \mathrm{l}$ of $0.2 \mathrm{M} \mathrm{HCl}$ solution were added and absorbance was measured on a microtiter plate reader (TECAN Spectrafluor plus, Switzerland) at $450 \mathrm{~nm}$.

\section{Antioxidant enzymes assays}

Antioxidant enzymatic activity of four enzymes: superoxide dismutase (SOD), glutathione peroxidase (GPX), gluthatione reductase (GRD) and catalase was determined.

\section{Superoxide dismutase (SOD)}

SOD activity was measured by optimization of the method that we used previously [20]. Enzymatic activity was measured as a decrease of the XTT (3'-(1-[(Phenylamino)-carbonyl]-3,4-tetrazolium)-bis(4-methoxy-6nitro) benzenesulphonic acid hydrate) reduction by superoxide anion generated by xanthine oxidase.
a) Xanthine $+\mathrm{O}_{2} \stackrel{\mathrm{XO}}{\longrightarrow}$ uric acid $+\mathrm{O}_{2}{ }^{-}$
b) $\mathrm{O}_{2}{ }^{--}+$XTT (detctor) $\rightarrow$ reduced XTT
c) $2 \mathrm{O}_{2}^{-{ }^{-}}+2 \mathrm{H}^{+} \stackrel{\mathrm{SOD}}{\longrightarrow} \mathrm{H}_{2} \mathrm{O}_{2}+\mathrm{O}_{2}$

The SOD activity was assessed as the competition between reaction $\mathrm{c}$ and $\mathrm{b}$ which is measured as a decrease of the rate of XTT reaction. The reaction mixture contained $40.5 \mathrm{mM}$ sodium phosphate buffer $\mathrm{pH} 7.8 ; 0.15$ $\mathrm{mM}$ xanthine; $0.15 \mathrm{mUI}$ xanthine oxidase, $30 \mathrm{mM}$ XTT and $20 \mu \mathrm{l}$ of sample to complete a final volume of $1 \mathrm{ml}$. The reaction was initiated by the addition of xantine oxidase, and the absorbable change at $470 \mathrm{~mm}$ was monitored for $3 \mathrm{~min}$ with a Hitachi spectrophotometer (U2000). One enzyme unit (IU) is defined as the amount of SOD capable of transforming $1.0 \mathrm{mmole} / \mathrm{min}$ of $\mathrm{O}_{2} \bullet$

\section{Glutathione peroxidase (GPX)}

GPX activity was measured by using a variation of the method previously used [20] based on that described by Paglia and Valentine [25]. Enzymatic activity was measured following the oxidation of glutathione (GSH) to oxidized glutathione (GSSG) catalysed by GPX and using as an electron acceptor ter-Butylhydroperoxide (t$\left.\mathrm{BuO}_{2} \mathrm{H}\right)$, coupled to the recycling of GSSG back to GSH utilizing GRD and NADPH.

$$
\begin{gathered}
\mathrm{ROOH}+2 \mathrm{GSH} \stackrel{\mathrm{GPX}}{\longrightarrow} \mathrm{ROH}+\mathrm{H}_{2} \mathrm{O}+\mathrm{GSSG} \\
\mathrm{GSSG}+\mathrm{NADPH}+\mathrm{H}^{+} \stackrel{\mathrm{GRD}}{\longrightarrow} 2 \mathrm{GSH}+\mathrm{NADP}^{+}
\end{gathered}
$$

The reaction mixture contained $300 \mathrm{mM}$ sodium phosphate buffer pH 7.2; EDTA $0.5 \mathrm{mM}, 54 \mathrm{mUI}$ of GRD; 85 $\mu \mathrm{M}$ NADPH; $2 \mathrm{mM}$ GSH; $1.2 \mathrm{mM} \mathrm{t}-\mathrm{BuO}_{2} \mathrm{H}$ and $30 \mu \mathrm{l}$ seminal plasma to complete a final volume of $1 \mathrm{ml}$. The absorbance change at $340 \mathrm{~nm}$ was monitored for $3 \mathrm{~min}$ with a Hitachi spectrophotometer (U-2000). One unit will cause the oxidation of $1.0 \mathrm{~mole} / \mathrm{min}$ of NADPH.

\section{Glutathione reductase (GRD)}

GRD activity was measured,by using a variation of the method described by Goldberg and Spooner [26]. Enzymatic activity was measured following the decrease in absorbance at $340 \mathrm{~nm}$ due to NADPH oxidation as a consequence of the GSSG reduction. The reaction mixture contained $300 \mathrm{mM}$ sodium phosphate buffer $\mathrm{pH} 7.2 ; 0.5$ mM EDTA; $85 \mu \mathrm{M}$ NADPH; $0.8 \mathrm{mM}$ oxidized glutathione (GSSG) and $50 \mu \mathrm{l}$ seminal plasma to complete a final volume of $1 \mathrm{ml}$. The absorbable change at $340 \mathrm{~nm}$ was monitored for 3 min with a Hitachi spectrophotometer (U2000). One unit will cause the oxidation of $1.0 \mathrm{mmole} /$ min of NADPH.

\section{Catalase}

Catalase activity was measured by using a variation of the method described by Marti et al. [20]. The enzymatic activity was determined by the decrease in absorbance due to $\mathrm{H}_{2} \mathrm{O}_{2}$ reduction to $\mathrm{H}_{2} \mathrm{O}$ and $\mathrm{O}_{2}$ in catalase presence.

$$
2 \mathrm{H} 2 \mathrm{O} 2 \stackrel{\text { Catalase }}{\longrightarrow} 2 \mathrm{H} 2 \mathrm{O}+\mathrm{O} 2
$$

The reaction mixture contained $50 \mathrm{mM}$ sodium phosphate buffer $\left(\mathrm{pH} \mathrm{7);30} \mathrm{mM} \mathrm{H}_{2} \mathrm{O}_{2}\right.$ and $30 \mu \mathrm{l}$ seminal plasma to complete a final volume of $1 \mathrm{ml}$. The absorbance change at $240 \mathrm{~nm}$ was monitored for $30 \mathrm{sec}$ with a Hitachi spectrophotometer (U-2000). One enzyme unit (IU) is defined as the amount of catalase capable of transforming $1.0 \mu \mathrm{mol} / \mathrm{min}$ of $\mathrm{H}_{2} \mathrm{O}_{2}$.

\section{Statistical analysis}

Monthly and seasonal results are shown as mean \pm S.E.M. of the number of samples assessed in each case. Distribution of the data was evaluated by the KolmogorovSmirnov test. Because melatonin data were not normally distributed, and had a log normal distribution, logarithm 
transformation of these data was carried out to perform statistical analysis.

Differences between breeding (August-February) and non-breeding (March-July) seasons were compared by means of an analysis of variance (ANOVA) test, and correlations between assessed parameters were compared by means of Pearson's bivariated correlation test. When correlation between parameters was significant, linear regression test were carried out. All statistical analysis was performed using SPSS (v.15.0) software.

\section{Results}

All studied samples presented measurable quantities of melatonin, testosterone and antioxidant enzymes.

Both hormones showed monthly variations, with a decrease after the winter solstice that reached the minimum in May (testosterone) or June and July (melatonin), and a rise in August that reached the maximum levels in October-November (Fig. 1, P $<0.01$ ). The variation of melatonin levels in ram seminal plasma was higher than that of testosterone, with low values (less than $50 \mathrm{pg} / \mathrm{ml}$ ) from March to July while from September to January it doubled or tripled this value $(>100 \mathrm{pg} / \mathrm{ml}, \mathrm{P}<0.01)$. A peak of a mean value of $208.95 \pm 10.45 \mathrm{pg} / \mathrm{ml}$ was found in October. Testosterone content in ram seminal plasma reached the minimum in May, increasing thereafter, and achieved the maximum value of $35.52 \pm 8.71 \mathrm{ng} / \mathrm{ml}$ in November (Fig. $1, \mathrm{P}<0.01$ ). Also, melatonin and testosterone values showed a marked seasonal variation in ram seminal plasma $(\mathrm{P}<0.01$, Table 1$)$, with low levels in the non-breeding season and high concentrations in the breeding one.

The yearly pattern of the four antioxidant studied enzymes is shown in Fig. 2. GRD activity was minimum in June and maximum in October- November $(\mathrm{P}<0.01)$, very close to the melatonin pattern. Likewise, the distribution of catalase was also close to that of melatonin, although the maximum value was achieved in August ( $\mathrm{P}$ $<0.05)$ decreasing thereafter. GPX and SOD activities were spread out along the year (Fig. 2).

Among the four antioxidant enzymes assessed, only GRD showed a significant seasonal variation $(\mathrm{P}<0.01)$ with a higher activity during the breeding season (Table 1). GPL and SOD activities did not show a seasonal distribution, and although marked monthly variations were found in catalase distribution, it was not significant $(\mathrm{P}=$ 0.11 )

Correlation analysis between the studied hormones and antioxidant enzymes showed a significant correlation between melatonin and testosterone, GRD, SOD and cat-

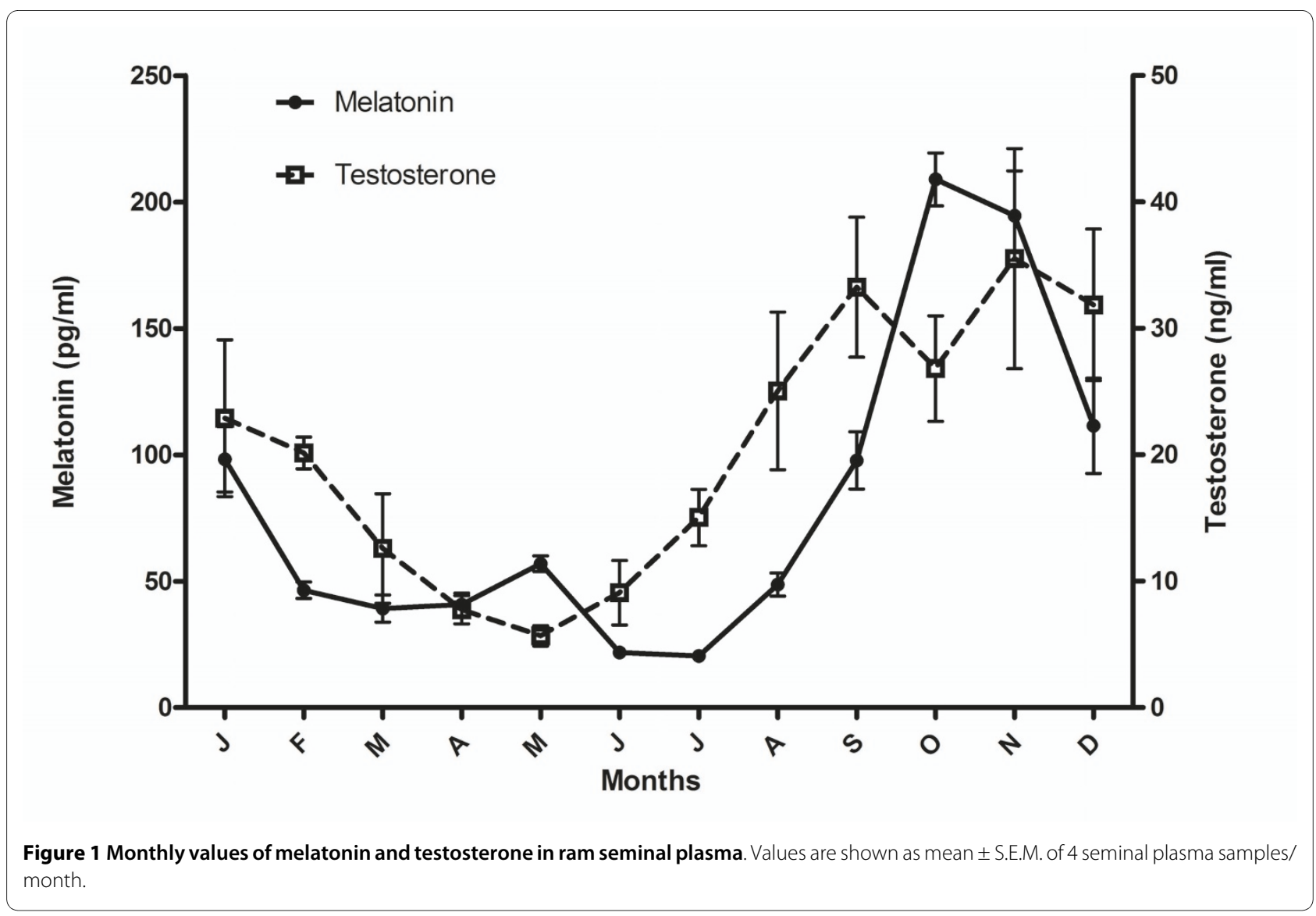


Table 1: Seasonal values of melatonin, testosterone and antioxidant enzyme activities in ram seminal plasma

\begin{tabular}{lcc}
\hline & $\begin{array}{c}\text { Breding season } \\
(\mathbf{n}=\mathbf{2 8})\end{array}$ & $\begin{array}{c}\text { Non breeding season } \\
\text { (n= 20) }\end{array}$ \\
\hline Melatonin $(\mathrm{pg} / \mathrm{ml})$ & $137.51 \pm 17.8^{\mathrm{a}}$ & $46.57 \pm 8.37^{\mathrm{b}}$ \\
Testosterone $(\mathrm{ng} / \mathrm{ml})$ & $28.13 \pm 3.35^{\mathrm{a}}$ & $10.66 \pm 2.92^{\mathrm{b}}$ \\
GPX $(\mathrm{nmole} / \mathrm{min} \cdot \mathrm{ml})$ & $61.57 \pm 4.48$ & $52.86 \pm 8.53$ \\
GRD $(\mathrm{nmole} / \mathrm{min} \cdot \mathrm{ml})$ & $11.82 \pm 0.84^{\mathrm{a}}$ & $7.5 \pm 0.47^{\mathrm{b}}$ \\
SOD $(\mathrm{mmole} / \mathrm{min} \cdot \mathrm{ml})$ & $8.86 \pm 0.15$ & $8.56 \pm 0.26$ \\
Catalase $(\mu \mathrm{mole} / \mathrm{min} \cdot \mathrm{ml})$ & $2.11 \pm 0.25$ & $1.74 \pm 0.19$ \\
\hline
\end{tabular}

Values are shown as mean \pm S.E.M. of the number of the number of seminal plasma samples assessed in brackets. Different letters in the same row account for significant differences between seasons $(P<0.01)$

alase. In addition, SOD showed a direct correlation with GRD and catalase, but not with testosterone or GPX (Table 2). A graphical representation of correlations and linear regression fit is sown in Fig. 3.

\section{Discussion}

The results of this study show the presence of melatonin and testosterone in ram seminal plasma, both hormones with a seasonal variation, in the same way as occurs in blood serum throughout the year $[27,28]$. In order to investigate the hypothesis that melatonin is functionally involved in the antioxidant defence system, we determined the activity of the main antioxidant enzymes in the same sample. The obtained data demonstrate a strong correlation between melatonin and testosterone, as well as between melatonin and the activity of three antioxidant enzymes (GRD, SOD and catalase) in ram seminal plasma, which supports the melatonin role in the regulation of both the male reproductive $[29,30]$ and the antioxidant enzyme defense [23] systems.

Melatonin is able to modulate the reproductive physiology in photoperiod-dependent seasonally breeding mammals [4-7]. Melatonin variation in ram seminal plasma shown here seems to reflect the seasonal variation of melatonin secretion by the pineal gland [31]. Given that the breeding season in sheep is regulated by photo period and melatonin [32], both seasonal [11,12] or melatonin $[14,30,33]$ effects on reproductive parameters in rams have been largely studied. Detrimental effects of long days, and beneficial effects of both short days or melatonin treatment in the non-breeding season were supposed to be due to the melatonin regulator effect on the hypothalamus-pituitary-testicular axis [27], modulating GnRH pulsativility [13] and gonadotropin and testosterone production $[34,35]$. However, we have recently proved a direct action of melatonin on ram spermatozoa, decreasing sperm apoptotic-like features and modulating sperm capacitation and fertilization rates [18]. Therefore, the high variation in melatonin concentration throughout the year in ram seminal plasma found in this study could partly explain differences in sperm quality and fertility observed between the breeding and non-breeding seasons $[10,16,17]$.

Similarly, testosterone levels also showed seasonal variation in ram seminal plasma, and they were significantly higher during the breeding season, which could influence fertility. Testosterone, produced by testes, is required for maturation of male germ cells and sperm production and quality [36]. Testosterone is metabolized to estrogens by aromatase [37], and estrogens seem to regulate ejaculated sperm motility [38]. The presence of testosterone and estrogen receptors in human spermatozoa $[39,40]$ and the strong correlation found between the aromatase expression and motility in human [41] and buffalo [42] ejaculated sperm suggest that aromatase could be involved in the modulation of sperm motility by metabolization of seminal plasma testosterone into estrogens. Therefore, the higher ram sperm quality [43] and fertilization rate [16] observed during the breeding season could be partially caused by high levels of testosterone in ram seminal plasma, which could be transformed into estrogens by aromatase and improve motility parameters. This theory is supported by our previous results which showed that melatonin implants in ram during the non-breeding season increased sperm progressive motility [17], although direct in vitro incubation of ram spermatozoa with different melatonin doses during the non-breeding season did not affect sperm motility [18]. The possibility that variations in motility parameters observed in ejaculates of melanin-implanted rams are due to an increase in locally produced estrogens by aromatase, as a result of high testosterone levels in seminal plasma, cannot be ruled out.

Seasonal variation of testosterone in ram seminal plasma is slightly lower than that of melatonin. Given that breeds can differ in their fluctuations of gonadotropin and testosterone levels in response to changes in day 

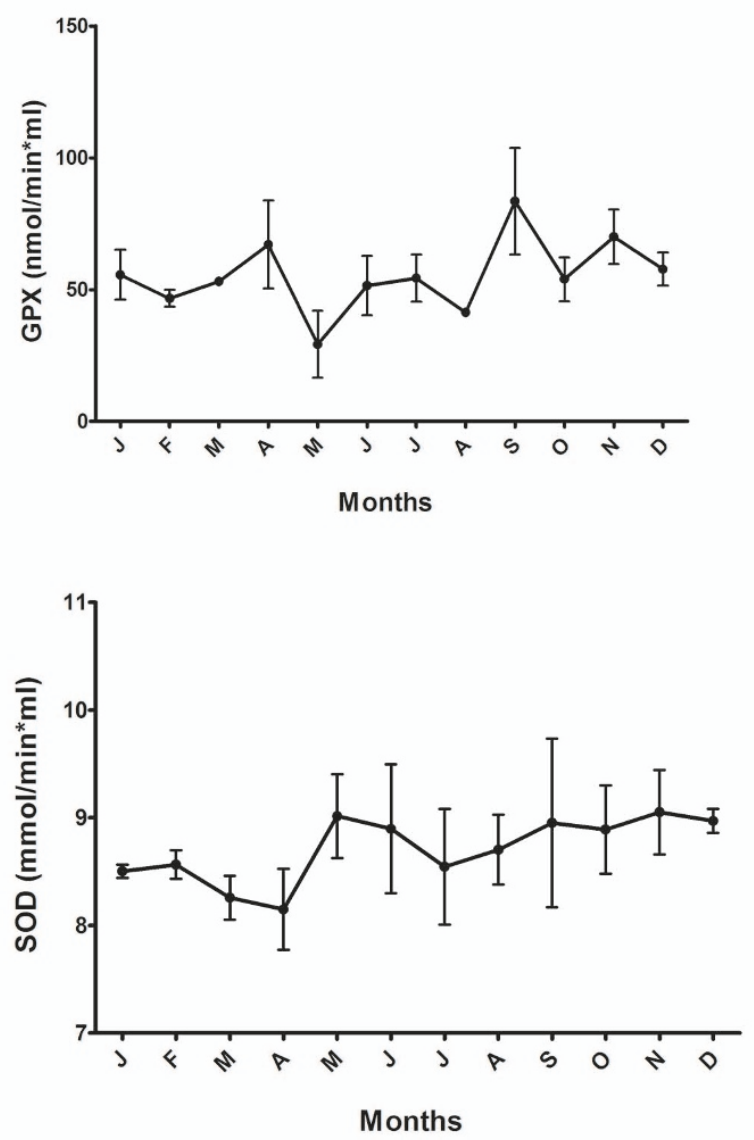
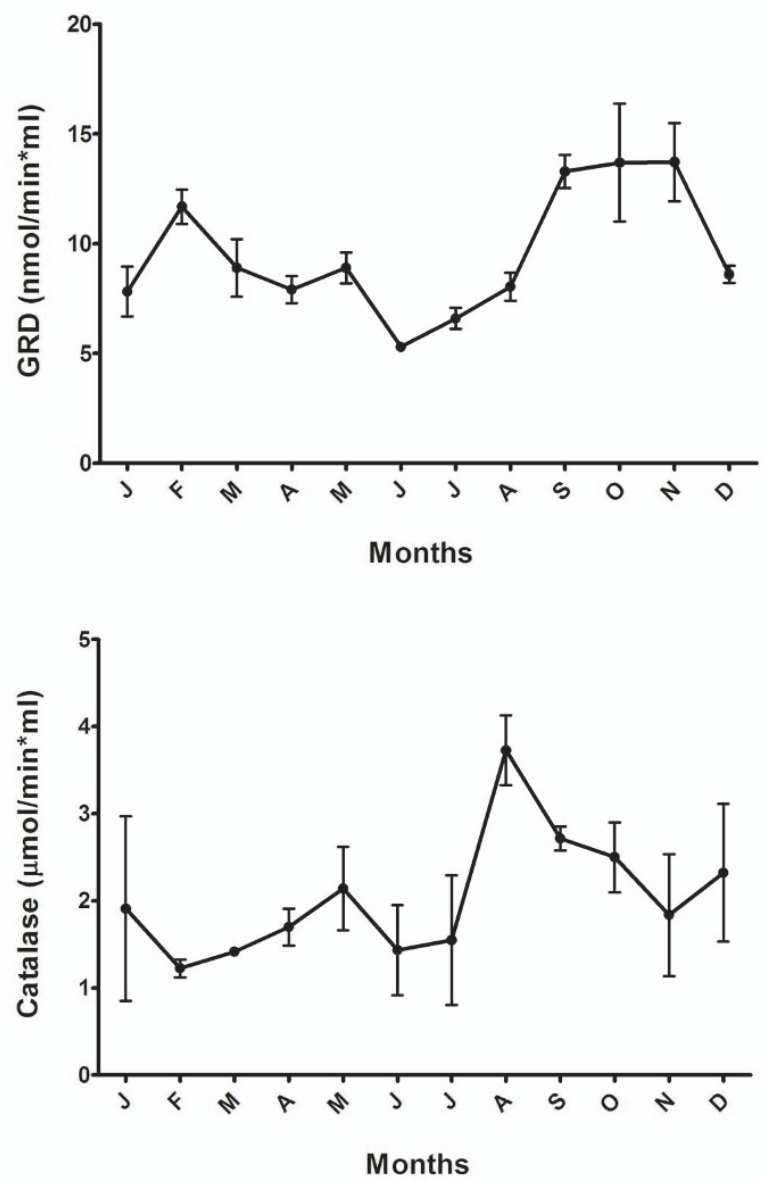

Figure 2 Monthly distribution of GRD, GPX, CAT, and SOD activities in ram seminal plasma. Values are shown as mean \pm SEM of 4 seminal plasma samples/month.

length and melatonin secretion [27], the minor testosterone variation may be a reflection of the short non-breeding season of Rasa Aragonesa breed [15]. The relationship between melatonin and testosterone has been well documented. The effect of melatonin on blood testosterone levels has been reported in various species, including ovine. Testosterone blood levels in ram are known to fluctuate throughout the year [27,34], and are increased by melatonin treatment during the non-breeding season [33]. The high correlation found in this study between the levels of melatonin and testosterone in ram seminal plasma is worth pointing out, and suggests that both hor-

Table 2: Pearson's correlations ( $r$ ) between melatonin, testosterone and antioxidant enzymes in ram seminal plasma

\begin{tabular}{lcccccc}
\hline & Melatonin & Testosterone & GPX & GRD & SOD & CAT \\
\hline Melatonin & 1 & $0.363^{*}$ & -0.009 & $0.509^{* *}$ & $0.411^{*}$ & $0.362^{*}$ \\
Testosterone & $0.363^{*}$ & 1 & 0.175 & 0.318 & 0.209 & 0.223 \\
GPX & -0.009 & 0.175 & 1 & 0.243 & -0.175 & -0.264 \\
GRD & $0.509^{* *}$ & 0.318 & 0.2431 & 1 & $0.393^{*}$ & 0.176 \\
SOD & $0.411^{*}$ & 0.209 & -0.175 & $0.393^{*}$ & $0.364^{*}$ & 1 \\
CAT & $0.362^{*}$ & 0.223 & -0.264 & 0.176 & $0.364^{*}$ & 1 \\
\hline
\end{tabular}

${ }^{*} \mathrm{P}<0.05$

${ }^{* * P}<0.01$ 

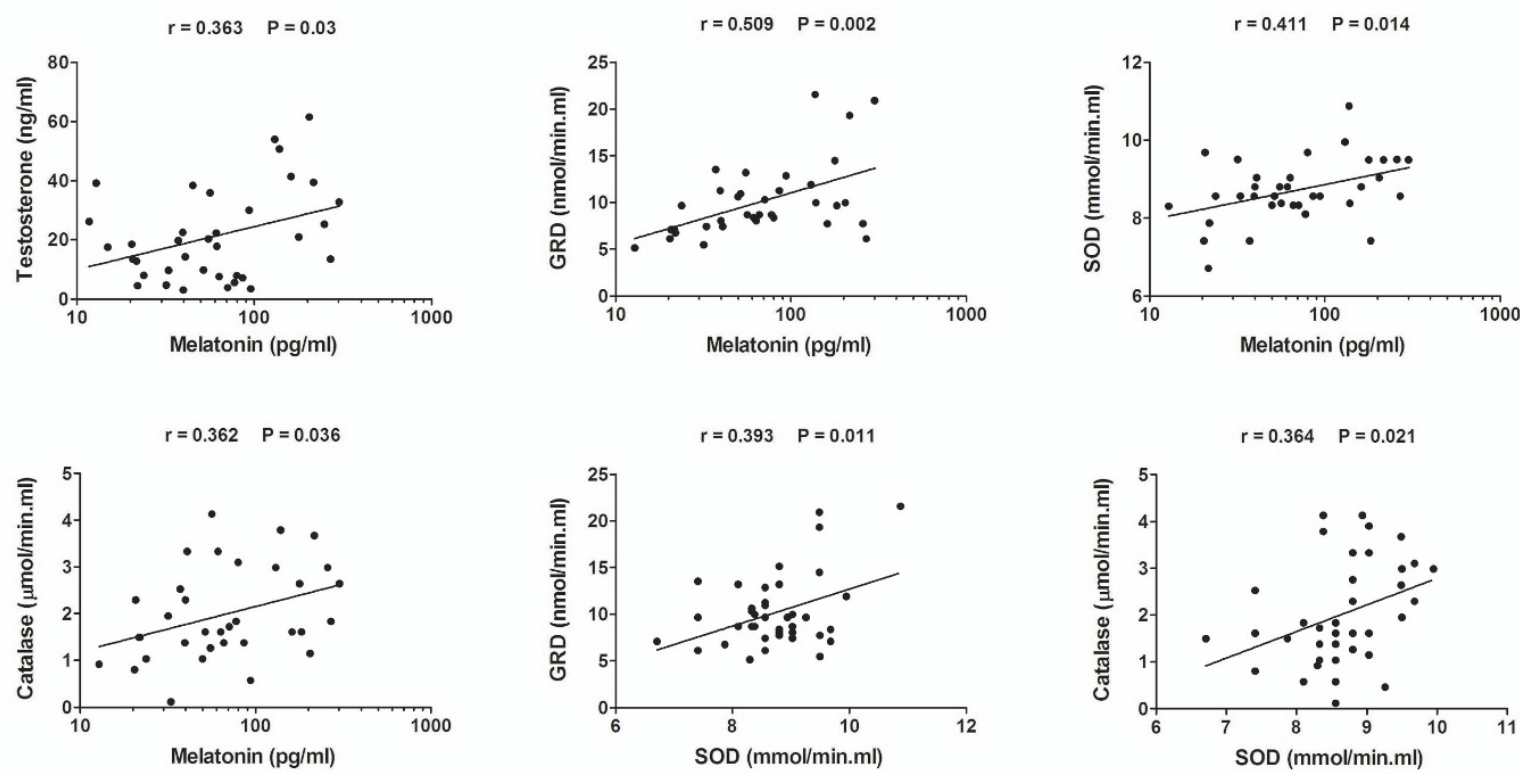

Figure 3 Graphical representation (scattered plot) of correlation and linear regression fit between hormones and antioxidant enzymes in 48 seminal plasma samples

mones are also closely related in this fluid, and could reflect changes in these blood hormones throughout the year.

On the other hand, spermatozoa are very sensitive to oxidative stress effects, and their fertilizing capacity is impaired due to early apoptosis and DNA damage [44]. To protect spermatozoa from ROS, epydidimal epithelium [45] and accessory sex glands secrete antioxidant enzymes as well as other free radical scavengers [46]. GRD, GPX and SOD are mainly secreted by the prostate, while catalase would be of multi-glandular origin [47]. Antioxidant enzyme activity shows endogenous daily cycles that may be regulated by Circadian melatonin rhythms [48].

In this study, we have found a seasonal variation of GRD in ram seminal plasma with significantly higher activity in the breeding season. The seasonal variation of GRD in ram seminal plasma found in this study, and the strong correlation between melatonin and GRD SOD and catalase suggest a seasonal regulation of these antioxidant enzymes by melatonin. The detection of melatonin receptor in rat epididymis [49] suggests a role for melatonin in the regulation of epididymis antioxidant enzyme production [23]. However, there is still no evidence of melatonin regulation of prostatic antioxidant enzyme production. Although melatonin receptors have been evidenced in human and rat prostate benign tumours [50,51], there are no reports of melatonin receptors in prostate of healthy males, which might mediate the prostatic production of antioxidant enzymes. However, the lipophilic nature of melatonin would allow this hormone to cross the plasma membranes, and thus its possible stimulatory effect on antioxidant enzyme production could be mediated by nuclear or cytosol binding sites [52]. Furthermore, melatonin is supposed to regulate antioxidant enzyme activity via melatonin plasma membrane receptors $\mathrm{MT}_{1} / \mathrm{MT}_{2}$ [23], increasing messenger RNA and protein levels of these enzymes [22]. Additionally, along with the direct effect of the antioxidant enzyme defence system, the high ability of melatonin to function in the reduction of oxidative stress could also involve the prevention of toxic effects of ROS in seminal plasma [53], as this indolamine directly neutralizes a high number of toxic free radicals [54].

\section{Conclusions}

In conclusion, this study demonstrates the presence of melatonin and testosterone in ram seminal plasma, and that both hormones have seasonal variations. The obtained results support the idea that melatonin is involved in the regulation of semen quality and the antioxidant enzyme activity that affect the reproductive performance of rams, and that seasonal variations of fertility in the ram involve an interplay between melatonin and the antioxidant defence system. Further investigations on this subject would be applicable to animal reproductive biology. 


\section{Competing interests}

The authors declare that they have no competing interests.

\section{Authors' contributions}

$J A C P$ and $A C$ designed the research, $A C$ performed melatonin and testosterone assays and drafted the manuscript, IC and MEODAA performed antioxidant enzymes assays, RPP and TMB carried out data analysis and interpretation, and TMB, FF and JAA revised and approved the article. All authors read and approved the final manuscript.

\section{Acknowledgements}

Supported by grants CICYT-FEDER AGL 2007-61229, CICYT-FEDER AGL 200801476, DGA A-26 and DGA 040/08. The authors thank ANGRA for supplying the sires and S. Morales for the collection of semen samples.

\section{Author Details}

'Departamento de Bioquímica y Biología Molecular y Celular, Grupo Biología y Fisiología de la Reproduction (BIOFREZ), Instituto Universitario de Investigation en Ciencias Ambientales de Aragón (IUCA), Facultad de Veterinaria, Universidad de Zaragoza, Spain, ${ }^{2}$ Departamento de Fisiologia, Facultad de Ciencias de la Salud y del Deporte. Universidad de Zaragoza, Spain, ${ }^{3}$ Departamento de Reprodução Animal de la Facultade de Medicina Veterinaria de la Universidade de Sao Paulo, Brasil and ${ }^{4}$ Departamento de Production Animal y Ciencia de los Alimentos, Grupo Biologìa y Fisiología de la Reproducción (BIOFREZ), Instituto Universitario de Investigación en Ciencias Ambientales de Aragón (IUCA), Facultad de Veterinaria, Universidad de Zaragoza, Spain

\section{Received: 7 April 2010 Accepted: 11 June 2010}

Published: 11 June 2010

\section{References}

1. Cajochen C, Kracchi K, wirz-justice A: Role of melatonin in the regulation of human circadian rhythms and sleep. J Neuroendocrinal 2003, 15:432-437.

2. Malpaux B, Migaud M, Tricoier H, Chemineau P: Biology of mammalian photoperiodic and the critical role of the pineal gland and melatonin. J Biol Rhythms 2001, 16:336-347.

3. Reiter RJ: Pineal melatonin: cell biology of its synthesis and of its physiological interactions. Endocr Rev 1991, 12:151-180.

4. Reiter RJ, Hester RJ: Interrelationships of the Pineal Gland, the Superior Cervical Ganglia and the Photoperiod in the Regulation of the Endocrine Systems of Hamsters. Endocrinology 1966, 79:1 168-1170.

5. Reiter RJ: Comparative Physiology: Pineal Gland. Annual Review of Physiology 1973, 35:305-328.

6. Stetson MH, Elliot JA, Menaker M: Photoperiodic Regulation of Hamster Testis: Circadian Sensitivity to the Effects of Light. Biol Reprod 1975, 13:329-339.

7. Terek FW, Desjardins C, Menaker M: Melanin-induced inhibition of testicular function in adult golden hamsters. Proc Soc Exp Biol Med 1976, 151:502-506.

8. Malpaux B, Viguie C, Skinner DC, Thiery AC, Pelletier J, Chemineau P: Seasonal breeding in sheep: Mechanism of action of melatonin. Anim Reprod Sci 1996, 42:109-117.

9. Bittman E, Karsch F, Hopkins J: Role of the pineal gland in ovine photoperiodism: regulation of seasonal breeding and negative feedback effects of estradiol upon luteinizing hormone secretion. Endocrinology 1983, 113:329-336.

10. Cardozo JA, Fernández-Juan M, Forcada F, Abecia A, Muiño-Blanco T, Cebrián-Pérez JA: Monthly variations in ovine seminal plasma proteins analyzed by two-dimensional polyacrylamide gel electrophoresis. Theriogenology 2006, 66:841-850.

11. Avdi M, Banos G, Stefos K, Chemineau P: Seasonal variation in testicular volume and sexual behavior of Chios and Seres rams. Theriogenology 2004, 62:275-282.

12. D'Alessandro AG, Martemucci G: Evaluation of seasonal variations of semen freezability in Leccese ram. Anim Reprod Sci 2003, 79:93-102.

13. Langford GA, Ainsworth L, Marcus GJ, Shrestha JN: Photoperiod entrainment of testosterone, luteinizing hormone, follicle- stimulating hormone, and prolactin cycles in rams in relation to testis size and semen quality. Biol Reprod 1987, 37:489-499.
14. Lincoln GA, Almeida OF, Arendt J: Role of melatonin and circadian rhythms in seasonal reproduction in rams. J Reprod Fertil Supp/1981, 30:23-31.

15. Forcada F, Abecia JA, Sierra I: Seasonal changes in oestrus activity and ovulation rate in Rasa Aragonesa ewes maintained at two different body condition levels. Small Rumin Res 1992, 8:313-324.

16. Palacín I, Abecia JA, Forcada F, Casao A, Cebrian-Perez JA, Muino-Blanco T, Palacios C, Pontes JM: Effect of exogenous melatonin treatment on out of season ram fertility. Italy J Anim Sci 2008, 7:199-206.

17. Casao A, Vega S, Palacín I, Pérez-Pe R, Laviña A, Quintín FJ, Seville E, Abecia JA, Cebrián-Pérez JA, Forcada F, Muiño-Blanco T: Effects of Melatonin Implants During Non-Breeding Season on Sperm Motility and Reproductive Parameters in Rasa Aragonesa Rams. Reprod Domest Anim 2010, 45:425-432.

18. Casao A, Mendoza N, Pérez-Pé R, Grasa A, Abecia JA, Forcada F, CebriánPeréz JA, Muino-Blanco T: Melatonin prevents capacitating and apoptotic-like changes of ram spermatozoa and increases fertility rate. J Pineal Res 2010, 48:39-46.

19. Sies $\mathrm{H}$ : Biochemistry of Oxidative Stress. Angewandte Chemise International Edition in English 1986, 25:1058-1071.

20. Marti E, Mara L, Marti JI, Muiño-Blanco T, Cebrián-Pérez JA: Seasonal variations in antioxidant enzyme activity in ram seminal plasma. Theriogenology 2007, 67:1446-1454.

21. Rosa HJD, Bryant MJ: Seasonality of reproduction in sheep. Small Rumin Res 2003, 48:155-171.

22. Reiter RJ, Tan DX, Osuna C, Gitto E: Actions of melatonin in the reduction of oxidative stress - A review. J Biomed Sci 2000, 7:444-458.

23. Rodriguez C, Mayo JC, Sainz RM, Anatolín I, Herrera F, Martín V, Reiter RJ: Regulation of antioxidant enzymes: a significant role for melatonin. $J$ Pineal Res 2004, 36:1-9.

24. Ollero M, Muino-Blanco T, Lopez-Perez MJ, Cebrian-Perez JA: Viability of ram spermatozoa in relation to the abstinence period and successive ejaculations. Int J Androl 1996, 19:287-292.

25. Paglia DE, Valentin W: Studies on quantitative and qualitative characterization of erythrocyte glutathione peroxidase. $\mathrm{J}$ Lab Clin Med 1967, 70:158.

26. Goldberg D, Sooner R: Glutathione reductase. Wiley-VCH; 1983.

27. D'Occhio MJ, Schanbacher BD, Kinder JE: Profiles of luteinizing hormone, follicle-stimulating hormone, testosterone and prolactin in rams of diverse breeds: effects of contrasting short (8L:16D) and long (16L:8D) photoperiods. Biol Reprod 1984, 30:1039-1054.

28. Lincoln GA, Clarke IJ: Refractoriness to a static melatonin signal develops in the pituitary gland for the control of prolactin secretion in the ram. Biol Reprod 1997, 57:460-467.

29. Almeida OF, Lincoln GA: Photoperiodic regulation of reproductive activity in the ram: evidence for the involvement of circadian rhythms in melatonin and prolactin secretion. Biol Reprod 1982, 27:1062-1075.

30. Fitzgerald JA, Stellflug JN: Effects of melatonin on seasonal changes in reproduction of rams. J Anim Sci 1991, 69:264-275.

31. Arendt J: Melatonin and the pineal gland: influence on mammalian seasonal and circadian physiology. Rev Reprod 1998, 3:13-22.

32. Chemineau P, Malpaux B, Delgadillo JA, Guerin Y, Ravault JP, Thimonier J, Pelletier J: Control of sheep and goat reproduction: Use of light and melatonin. Anim Reprod Sci 1992, 30:157-184.

33. Kaya A, Baspinar N, Yildiz C, Kurtoglu F, Ataman MB, Haliloglu S: Influence of melatonin implantation on sperm quality, biochemical composition of the seminal plasma and plasma testosterone levels in rams. Rev Med Vet 2000, 151:1143-1146.

34. Lincoln GA, Lincoln CE, McNeilly AS: Seasonal cycles in the blood plasma concentration of FSH inhibin and testosterone, and testicular size in rams of wild, feral and domesticated breeds of sheep. J Reprod Fertil 1990, 88:623-633.

35. Schanbacher BD, Lunstra DD: Seasonal changes in sexual activity and serum levels of $\mathrm{LH}$ and testosterone in Finish Landrace and Suffolk rams. J Anim Sci 1976, 43:644-650

36. Walker WH: Molecular mechanisms of testosterone action in spermatogenesis. Steroids 2009, 74:602-607.

37. Simpson ER, Mahendroo MS, Means GD, Kilgore MW, MM H, GrahamLorence S, Bilal A, Ito Y, Fisher CR, Michael MD, Mendelson CR, Bulun SE: Aromatase Cytochrome P450, The Enzyme Responsible for Estrogen Biosynthesis. Endocr Rev 1994, 15:342-355. 
38. Carreau S, Silandre D, Bois C, Bouraima H, Galeraud-Denis I, Delalande C: Estrogens: a new player in spermatogenesis. Folia Histochem Cytobiol 2007, 45(Suppl 1):S5-10.

39. Solakidi S, Psarra AM, Nikolaropoulos S, Sekeris CE: Estrogen receptors alpha and beta (ERalpha and ERbeta) and androgen receptor (AR) in human sperm: localization of ERbeta and AR in mitochondria of the midpiece. Hum Reprod 2005, 20:3481-3487.

40. van Vuuren RJ, Pitout MJ, van Aswegen $\mathrm{CH}$, Theron JJ: Putative melatonin receptor in human spermatozoa. Clin Biochem 1992, 25:125-127.

41. Lambard S, Galeraud-Denis I, Bouraima H, Bourguiba S, Chocat A, Carreau S: Expression of aromatase in human ejaculated spermatozoa: a putative marker of motility. Mol Hum Reprod 2003, 9:117-124.

42. Tiwari A, Singh D, Kumar OS, Sharm MK: Expression of cytochrome P450 aromatase transcripts in buffalo (Bubalus bubalis)-ejaculated spermatozoa and its relationship with sperm motility. Domest Anim Endocrinol 2008, 34:238-249.

43. Karagiannidis A, Varsakeli S, Alexopoulos C, Amarantidis I: Seasonal variation in semen characteristics of Chios and Friesian rams in Greece. Small Rumin Res 2000, 37:125-130.

44. Martinez-Pastor F, Aisen E, Fernandez-Santos MR, Esteso MC, MarotoMorales A, Garcia-Alvarez O, Garde JJ: Reactive oxygen species generators affect quality parameters and apophysis markers differently in red deer spermatozoa. Reproduction 2009, 137:225-235.

45. Potts RJ, Jefferies TM, Notarianni $\sqcup$ : Antioxidant capacity of the epididymis. Hum Reprod 1999, 14:2513-2516.

46. Wai-sum $\mathrm{O}$, Chen $\mathrm{H}$, Chow PH: Male genital tract antioxidant enzymes-Their ability to preserve sperm DNA integrity. Mol Cell Endocrinol 2006, 250:80-83.

47. Yeung CH, Cooper TG, De Geyter M, De Geyter C, Rolf C, Kamischke A, Nieschlag E: Studies on the origin of redox enzymes in seminal plasma and their relationship with results of in-vitro fertilization. Mol Hum Reprod 1998, 4:835-839.

48. Albarran MT, Lopez-Burillo S, Pablos MI, Reiter RJ, Agapito MT: Endogenous rhythms of melatonin, total antioxidant status and superoxide dismutase activity in several tissues of chick and their inhibition by light. J Pineal Res 2001, 30:227-233.

49. Shiu SY, Li L, Siu SW, Xi SC, Fong SW, Pang SF: Biological basis and possible physiological implications of melatonin receptor-mediated signaling in the rat epididymis. Biol Signals Recept 2000, 9:172-187.

50. Gilad E, Laudon M, Matzkin H, Zisapel N: Evidence for a local action of melatonin on the rat prostate. The Journal of Urology 1998, 159:1069-1073.

51. Gilad E, Laudon M, Matzkin H, Pick E, Sofer M, Barf Z, Zisapel N: Functional melatonin receptors in human prostate epithelial cells. Endocrinology 1996, 137:1412-1417.

52. Tomas-Zapico C, Colo-Montes A: A proposed mechanism to explain the stimulatory effect of melatonin on antioxidative enzymes. $J$ Pineal Res 2005, 39:99-104

53. Sainz RM, Mayo JC, Rodriguez C, Tan DX, Lopez-Burillo S, Reiter RJ: Melatonin and cell death: differential actions on apoptosis in normal and cancer cells. Cell Mol Life Sci 2003, 60:1407-1426.

54. Tan DX, Chen LD, Poeggeler B, Manchester LC, Reiter RJ: Melatonin: a potent endogenous hydroxy radical scavenger. Endocr J 1993, 1:57-60

doi: $10.1186 / 1477-7827-8-59$

Cite this article as: Casao et al., Seasonal variations of melatonin in ram seminal plasma are correlated to those of testosterone and antioxidant enzymes Reproductive Biology and Endocrinology 2010, 8:59

\section{Submit your next manuscript to BioMed Central and take full advantage of:}

- Convenient online submission

- Thorough peer review

- No space constraints or color figure charges

- Immediate publication on acceptance

- Inclusion in PubMed, CAS, Scopus and Google Scholar

- Research which is freely available for redistribution

Submit your manuscript at www.biomedcentral.com/submit
C BioMed Central 